IRA-International Journal of Management \& Social Sciences

ISSN 2455-2267; Vol.04, Issue 02 (2016)

Pg. no. 447-454

Institute of Research Advances

http://research-advances.org/index.php/RAJMSS

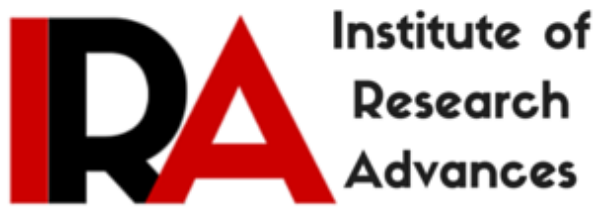

\title{
A Study of Motivators of Tender Offer Repurchases in the Indian Environment
}

\author{
Urvashi Varma $^{1}$ and Prof (Dr) Alka Munjal ${ }^{2}$ \\ ${ }^{1}$ Research Scholar. Amity University, Noida, India. \\ ${ }^{2}$ Dean Student Academic Affairs and Support Services. \\ Amity University, Noida, India.
}

Type of Review: Peer Reviewed.

DOI: http://dx.doi.org/10.21013/jmss.v4.n2.p14

\section{How to cite this paper:}

Varma, U., \& Munjal, A. (2016). A Study of Motivators of Tender Offer Repurchases in the Indian Environment. IRA-International Journal of Management \& Social Sciences (ISSN 2455-2267), 4(2), 447-454. doi:http://dx.doi.org/10.21013/jmss.v4.n2.p14

(C) Institute of Research Advances

(cc) EY-NC

This work is licensed under a Creative Commons Attribution-Non Commercial 4.0 International License subject to proper citation to the publication source of the work.

Disclaimer: The scholarly papers as reviewed and published by the Institute of Research Advances (IRA) are the views and opinions of their respective authors and are not the views or opinions of the IRA. The IRA disclaims of any harm or loss caused due to the published content to any party. 


\begin{abstract}
Share buybacks are a 15 year old process in India. In developed countries share buyback is a wellaccepted practice but in India the concept has yet to gain popularity. The article tries to look at the tender offer repurchases in Indian between the periods 2004 to September 2013. There were 51 public announcements for share buyback through tender offer route. The other popular method is open market repurchase. The paper tries to identify the main drivers in the tender offer repurchase through regression analysis. The more significant drivers are reduction of earnings per share through buyback, correction in capital structure and improvement in return ratios like return on net worth. The paper also looks at identifying the impact on promoter's holding through tender offer buyback and identify if it is one of the drivers of share buyback.
\end{abstract}

Keywords: Share buyback, SEBI buyback regulations 1998, Tender offer.

\title{
JEL Classification: G35, G15
}

\section{INTRODUCTION}

Share repurchase refers to the process of a company buying back its shares from its existing shareholders (Damodaran, 2008). The buyback activity in India stared in 1998. In 1998, section 77A was introduced in The Companies Act 1956, which applies to all types of shares and other securities that may be bought back. With this amendment companies were allowed to buy back their shares, subject to statutory regulations. In India there have been 188 share buybacks announcements between years 2000 to $2011 .^{1}$ Company in Indian may buyback its own shares or other specified securities from the existing security holder on a proportionate basis through the tender offer or from the open market through either book building process or through stock exchange or from the odd-lot holders.

Share buyback in India is 15 year old process and has not been accepted in the magnitude as has been accepted by developed countries like US and UK. The reasons for lower acceptance needs to be investigated by looking at the regulations that govern share buyback. Along with it there is a need to identify drives of share buyback in India.

The present study focuses on identifying the drivers of tender offer share repurchase in the Indian set up. The study identifies through literature survey the prevalent drivers or motivators for share buyback and tries to investigate the key drivers in the Indian set up.

The impact of share buyback on a company is in terms of reduction in cash, reduction in outstanding shares, reduction in book value of equity and improvement in EPS(Damodaran,2008). Grullon and Ikenberry(2003) suggest that there is no single reason for buy back. They suggested that firms repurchase to boost their EPS. The study looks at improvement in EPS as one of the drivers of buyback. Ditter (2000) studies the relationship of share repurchase with excess cash, capital structure, and control and compensation policies. Medury, Bowyer and Srinivasan (1992) try to explain the stock repurchasing behaviour on the basis of leverage adjustment hypothesis; free cash flow hypothesis, the clientele hypothesis and anti-takeover hypothesis. Capital structure correction is again identified as one of the reasons for share buyback to be studied in the Indian context.

There are two schools of thought when we say dividends are substituted by repurchases. One suggesting that the dividends cannot be substituted by repurchases since both serve different signalling purpose. The study looks at investigating that is this phenomenon of substituting between buyback and dividends observable in tender offer share buyback in India.

Mishra (2005) observed companies going in for buyback were undervalued, have low promoter's stake, potential of takeover, and surplus cash in treasury, low debt equity ratio and high ROCE. He related that high ROCE signifies high free cash. The study tries to look into the aspect of profitability and promoters stake to identify if they act as drivers in the Indian context.

\footnotetext{
${ }^{1}$ www.sebi.gov.in
} 


\section{RESEARCH METHODOLOGY}

The objective of the study is to determine the underlying drivers for tender offer share buyback in India. The study tries to identify if there is significant impact of drivers like capital structure correction, improvement in earnings per share, higher profitability and dividend pay-out as a substitute method for returning excess cash on the buyback through tender offer method. To find out the result 26 announcements have been analysed.

In between January 2004 to September 2013 there have been 51 public announcements for Tender offer share buyback ${ }^{2}$. The present sample consists of 26 companies which have repurchased between the periods January 2007 to September 2013. Mishra (2005) has also used a sample of 25 announcements in his study.

The median values have been used to identify the size of buyback in terms of numbers of shares repurchased, shares repurchased as a percentage of the fully paid up capital, shares bought back as a percentage of total number of shares, maximum buyback price, the buyback offer size in rupees, buyback share premium and maximum number of shares bought back.

The drivers identified for capital structure correction is debt equity ratio. Medury, Bowyer and Srinivasan (1992) have used debt to equity as measure of capital structure. The dividend policy is popularly measured dividend pay-out as stated by Damodaran(2008). Profitability ratio can be measured either in terms of capital employed or in terms of sales (Damodaran 2008). In this study profitability is measured by the returns on net worth.

\section{Testing Tool : Model of the study}

The survey on literature has been utilised to draw a model for testing the drivers of repurchase which has been given below :

$\mathrm{N}=\alpha+\beta_{1} \mathrm{DE}+\beta_{2} \mathrm{EPS}+\beta_{3} \mathrm{RONW}+\beta_{4} \mathrm{DIV}+€$

$\mathrm{N}$ is the number of shares bought back.

$\mathrm{DE}$ is the debt equity ratio of the company before share buyback.

EPS is the earnings per share of the company before share buyback.

RONW is the return on net worth of the company before share buyback.

DIV is the dividend pay-out ratio of the company before share buyback.

\section{Motivations for Share Buyback}

Companies having excess cash and in dearth of profitable investments go in for buyback. They usually encounter agency conflict. The management acts in its own interest rather than the interest of the shareholders. It results in overinvestment in unprofitable investments and underinvestment in potentially profitable investments. To deter the improper utilization of this excess free cash companies go in for share buyback. Such companies benefit most from buyback and they do so to minimize excess cash. (Chan, Ikenberry and Lee, 2003)Buyback, by itself increases the leverage of the company by reducing the book value of equity. Hence it acts as a method for capital restructuring for the company. Share repurchase may be beneficial for companies that perceive its current leverage is below optimal target. So companies with low leverage benefit more from share repurchase (Chan, Ikenberry and Lee, 2003). Studies conducted previously have witnessed such capital structure correction more in overvalued companies than in undervalued companies, where the leverage ratio improves significantly post buy back ( D'Mello and Shroff 2000). Takeover deterrence is also one of the popular reasons for share buyback. Companies which are potential targets for takeovers usually go

\footnotetext{
${ }^{2}$ Source : www.sebi.gov.in
} 
in for share buyback to increase the share price of the company and hence making takeover difficult for the acquirer.This is more prevalent in firms which are overvalued and still go in for share repurchase. (D'Mello and Shroff 2000)

There are two schools of thought when we say dividends are substituted by repurchases . One suggesting that the dividends cannot be substituted by repurchases since both serve different signalling purpose. Dividends are used to signal a company's future prospects while repurchases signal undervaluation. The other school of thought suggests that both dividends and repurchases signal for undervaluation and agency conflicts and can be used as substitutes (Grullon and Michaely, 2002). In the present study we try to test this issue by considering dividend substitution as one of the hypotheses.Dividends and share buybacks serve the same purpose, of returning excess cash to the shareholders. The basic difference lies in the nature of customer we are dealing with. Dividends are paid to all the shareholders while buyback is made to the shareholders who are willing to surrender their shares and discontinue their association with the firm completely or partially. Such shareholders are referred as tendering shareholders. They tender their shares to the companies. The shareholders who do not wish to tender their shares are called non tendering shareholders. Distribution of excess cash through repurchase subjects the shareholders to capital gain tax. Dividend distribution is subject to dividend distribution $\operatorname{tax}^{3}$ in the hands of the companies. It is seen that capital gain tax is preferred by high net worth tax payers. Hence due to their taxation impact, dividends and share repurchase act as substitutes.

\section{SAMPLE AND DATA}

The sample of companies for the study is provided in the Table 3.1 and Graph 3.1 presents the trend of the number of tender offer in between period 2004 to 2013. There has been an observable decrease in the buyback through the tender offer over years and hence it becomes even more important to investigate the drivers for tender offer repurchase.

\footnotetext{
${ }^{3}$ Dividend income (as referred u/s 115-O of the I.Tax Act 1961) paid by Companies and Mutual Funds are exempt from tax. A $15 \%$ dividend distribution tax and surcharge of $3 \%$ is paid by companies before distribution.
} 
IRA-International Journal of Management \& Social Sciences

\begin{tabular}{|c|c|c|c|}
\hline \multicolumn{3}{|c|}{ TABLE 3.1 :SAMPLE OF COMPANIES } \\
\hline Sr No & Date of Announcement & Company & $\begin{array}{c}\text { Maximum No of } \\
\text { shares to be bought } \\
\text { back }\end{array}$ \\
\hline 1 & Sep 20, 2013 & Bayer CropScience Limited & $28,79,746$ \\
\hline 2 & Feb 15, 2013 & Graviss Hospitality Limited & $1,59,25,925$ \\
\hline 3 & Jan 21, 2013 & The Sandesh Limited & $9,60,000$ \\
\hline 4 & May 26, 2011 & Amrutanjan Health Care Limited & $1,06,937$ \\
\hline 5 & Dec 10, 2010 & Piramal Healthcare Limited & $41,80,2,629$ \\
\hline 6 & Nov 16, 2010 & Navin Fluorine Buyback & $3,38,792$ \\
\hline 7 & Jun 21, 2010 & Binanci Cement Limited & $1,45,00,000$ \\
\hline 8 & May 19,2010 & Geodesic Limited & $20,46,919$ \\
\hline 9 & Feb 26, 2010 & Gujarat Petrosynthese Limited & $12,11,762$ \\
\hline 10 & Feb 22, 2010 & Gee Cee Ventures Limited & $40,50,000$ \\
\hline 11 & Oct 16, 2009 & Zensar Technologies Limited & $24,24,000$ \\
\hline 12 & Feb 06, 2009 & Eicher Motors Ltd. & $14,08,968$ \\
\hline 13 & Dec 23, 2008 & Binani Metals Ltd. & 2350 \\
\hline 14 & Jul 29, 2008 & Gateway Distriparks Ltd & $58,18,181$ \\
\hline 15 & Jun 11,2008 & SRF Ltd & $43,75,000$ \\
\hline 16 & Apr 29, 2008 & Goldiam International Ltd & $14,86,804$ \\
\hline 17 & Apr 22, 2008 & Sasken Communication Technologies Ltd. & $15,38,461$ \\
\hline 18 & Apr 17, 2008 & Mastek Limited & $8,66,666$ \\
\hline 19 & Apr 17, 2008 & Great Offshore Ltd & $7,36,546$ \\
\hline 20 & Apr 15, 2008 & Patni Computer Systems Limited & $72,92,308$ \\
\hline 21 & Mar 12, 2008 & Reliance Energy Limited & $5,91,32,565$ \\
\hline 22 & Feb 14, 2008 & Madras Cements Ltd & $1,53,506$ \\
\hline 23 & Oct 05, 2007 & Assam Carbon Limited & $4,00,000$ \\
\hline 24 & Sep 26, 2007 & Hindustan Unilever Limited & $2,20,67,76,097$ \\
\hline 25 & Aug 13, 2007 & GTL Limited & $86,29,333$ \\
\hline 26 & Apr 27, 2007 & Ace Software Limited & $4,42,346$ \\
\hline
\end{tabular}

Source: Compiled by authors using data from SEBI

Graph 3.1: Trend of the number of tender offer in between period 2004 to 2013.

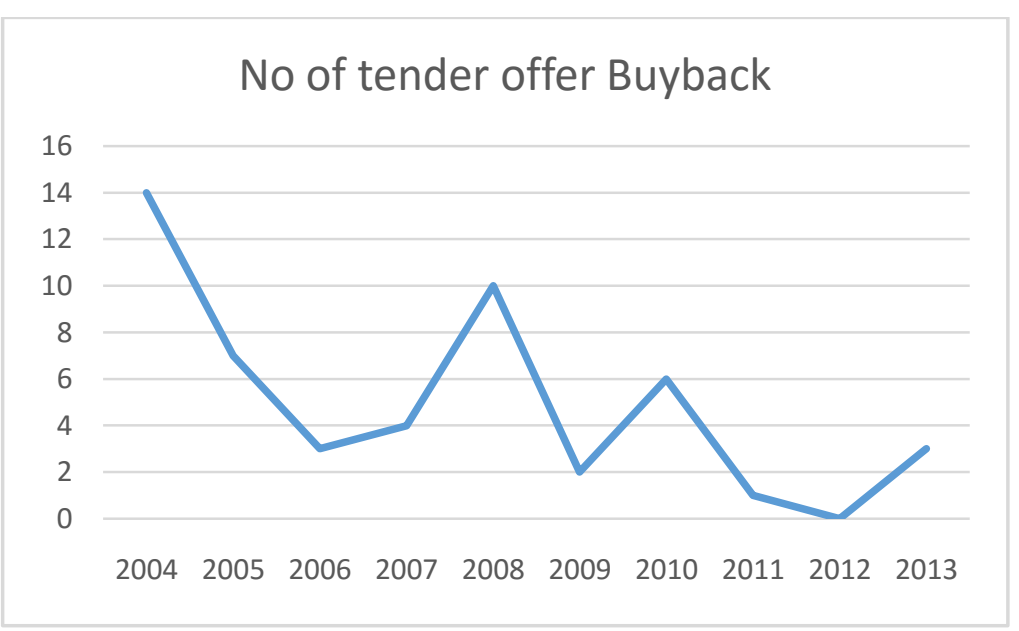

Source: Compiled by authors using data from SEBI 
Table 3.2: Median values for Tender offers between 2007 to 2013

\begin{tabular}{|r|l|r|}
\hline $\begin{array}{l}\text { Sr } \\
\text { No }\end{array}$ & Data Descriptor & Median Values \\
\hline 1 & $\begin{array}{l}\text { Shares bought back as a percentage of fully } \\
\text { paid equity }\end{array}$ \\
\hline 2 & $\begin{array}{l}\text { Shares bought back as a percentage of total } \\
\text { number of shares }\end{array}$ & $5 \%$ \\
\hline 3 & Maximum Buyback Price & Rs 230 \\
\hline 4 & Buyback Offer Size(in Rs) & $55,24,00,000$ \\
\hline 5 & Buyback Share premium & $24 \%$ of share price \\
\hline 6 & Maximum number of shares bought back & $15,38,461$ \\
\hline
\end{tabular}

Source : Computed by authors using SPSS using Tender Offer Buyback data from SEBI website.

The data on tender offer buyback suggests that a median value of $10 \%$ of the shares are bought back as a percentage of the fully paid up equity and $5 \%$ of the shares are being bought back as a percentage of total number of shares. The shares have been repurchased at a premium.

\section{ANALYSIS AND FINDINGS}

The study has identified debt equity ratio as a measure of capital structure, return on net worth as a measure of profitability, dividend pay out as a measure of alternate mode to return cash to shareholder and earnings per share as a measure of value to shareholder. These variable selection have been found in prior studies of Damodaran (2008), Horn, Wachowicz and Bahaduri ( 2008) and Asquith and Mullins (1986)

Table 4.1 : Median Values of Financial Performance Indicator of Buyback Companies

\begin{tabular}{|r|l|r|}
\hline Sr No & $\begin{array}{l}\text { Financial Performance Indicator of } \\
\text { Buyback Companies }\end{array}$ & \multicolumn{2}{|l|}{ Median Values } \\
\hline 1 & Debt equity ratio & 0.160 \\
\hline 2 & Earnings per share & 8.73 \\
\hline 3 & Return on net worth & $14.92 \%$ \\
\hline 4 & Dividend Pay out & $28.62 \%$ \\
\hline
\end{tabular}

Source : Computed by authors using SPSS using Tender Offer Buyback data from Annual report of companies.

The median values of the drives have been found out. The debt equity ratio is moderately low for the repurchasing companies. The earnings per share also has a moderate value. We do not see a very high earnings per share value. The return on net worth is high for the buyback companies and dividend payout is also high.

\section{Regression Results}

Model fit is provided in Tables 4.2. The drivers of dividend substitution, low earnings per share, capital structure correction and profitability undertaken in the study explain the buyback activity in terms of number of shares bought back by $90 \%$.

Table 4.2 : Model Fit

\begin{tabular}{|c|c|c|c|c|}
\hline \multicolumn{5}{|c|}{ Model Summary } \\
\hline $\begin{array}{l}\text { Mod } \\
\text { el }\end{array}$ & $\mathrm{R}$ & $\begin{array}{c}\mathrm{R} \\
\text { Square }\end{array}$ & $\begin{array}{l}\text { Adjusted R } \\
\text { Square }\end{array}$ & $\begin{array}{l}\text { Std. Error of } \\
\text { the Estimate }\end{array}$ \\
\hline 1 & $.949^{\mathrm{a}}$ & .900 & .881 & $\begin{array}{r}148693025 \\
18456\end{array}$ \\
\hline
\end{tabular}


Table 4.3: ANNOVA

\begin{tabular}{|c|c|c|c|c|c|c|}
\hline \multicolumn{7}{|c|}{ ANOVA $^{\mathbf{a}}$} \\
\hline \multicolumn{2}{|c|}{ Model } & Sum of & df & Mean & $\mathrm{F}$ & Sig. \\
\hline \multirow[t]{3}{*}{1} & $\begin{array}{l}\text { Regressio } \\
\mathrm{n}\end{array}$ & $\begin{array}{r}4192658966 \\
390761500 . \\
000\end{array}$ & 4 & $\begin{array}{r}1048164741 \\
597690370 . \\
000\end{array}$ & 47.408 & $.000^{\mathrm{b}}$ \\
\hline & Residual & $\begin{array}{r}4643019305 \\
09290240.0 \\
00\end{array}$ & 21 & $\begin{array}{r}2210961573 \\
8537632.00 \\
0\end{array}$ & & \\
\hline & Total & $\begin{array}{r}4656960896 \\
900052000 . \\
000\end{array}$ & 25 & & & \\
\hline
\end{tabular}

Table 4.4 : Coefficients and their significance

Coefficients $^{\mathbf{a}}$

\begin{tabular}{|c|c|c|c|c|c|c|}
\hline \multicolumn{2}{|c|}{ Model } & \multicolumn{2}{|c|}{ Unstandardized Coefficients } & \multirow{2}{*}{$\begin{array}{l}\text { Standardize } \\
\mathrm{d} \\
\text { Coefficients } \\
\text { Beta }\end{array}$} & \multirow[t]{2}{*}{$\mathrm{t}$} & \multirow[t]{2}{*}{ Sig. } \\
\hline & & B & Std. Error & & & \\
\hline \multirow[t]{5}{*}{1} & $\begin{array}{l}\text { (Constan } \\
\text { t) }\end{array}$ & $\begin{array}{r}- \\
28708415.2 \\
14\end{array}$ & $\begin{array}{r}51516218.8 \\
70\end{array}$ & & -.557 & .583 \\
\hline & de & $\begin{array}{r}- \\
224630665 . \\
977\end{array}$ & $\begin{array}{r}47974900.4 \\
01\end{array}$ & -.336 & -4.682 & .000 \\
\hline & eps & $\begin{array}{r}- \\
7667190.39 \\
8\end{array}$ & $\begin{array}{r}1626006.23 \\
2\end{array}$ & -.348 & -4.715 & .000 \\
\hline & ronw & $\begin{array}{r}14100338.2 \\
31\end{array}$ & $\begin{array}{r}1542685.28 \\
8\end{array}$ & .847 & 9.140 & .000 \\
\hline & divpay & $\begin{array}{r}2836045.91 \\
3\end{array}$ & $\begin{array}{r}1230425.80 \\
2\end{array}$ & .203 & 2.305 & .031 \\
\hline
\end{tabular}

a. Dependent Variable: NumShare

All the drivers have been found out to be significantly impacting the buyback activity. The signs of the coefficients explain the relationship. Debt to equity has an inverse relation with buyback. Earnings per share has an inverse relationship with buyback. RONW has positive relationship with buyback and Dividend pay-out has positive relationship with buyback. The comparison of the expected sign of the drivers of repurchase and the observed signs have been tabulated in Table 4.5.

Table 4.5 represents the comparison of the result with the theory on buy back

\begin{tabular}{|r|l|l|l|}
\hline Sr No & Variables & Expected Sign & $\begin{array}{l}\text { Observed Sign from } \\
\text { study }\end{array}$ \\
\hline 1 & Debt equity ratio & Negative & Negative \\
\hline 2 & Earnings per share & Negative & Negative \\
\hline 3 & Return on net worth & Positive & Positive \\
\hline 4 & Dividend Pay out & Negative & Positive \\
\hline
\end{tabular}

Source: Compiled by the authors on the basis of results of the study using data from SEBI and annual report of companies. 


\section{CONCLUSION}

The study concludes by finding that increasing the earnings per share is an important reason for companies to proceed for tender offer repurchase as has been stated by D'Mello and Shroff (2000) and Gustavo Grullon and David L. Ikenberry (2003). Capital structure correction is a significant driver for tender offer buyback in the study which is similar to study of Ditter (2000). Dividend payout has a positive relationship with buyback in the study hence the study finds out that dividend payout and share buyback are not substitutes to each other in the Indian environment supported by the study of Ditter (2000). Finally it has been observed that companies with higher profitability buyback through the tender offer route. A similar finding has been Mishra (2005).

\section{LIMITATIONS AND SCOPE FOR FURTHER RESEARCH}

The study is limited only to 26 companies and drivers of dividend substitution, low earnings per share, capital structure correction and profitability undertaken in the study. The study can further be conducted by adding more companies to the sample or by adding more drivers to the study like undervaluation. The study is also limited to only share buybacks through tender offer . The scope of the study can be increased by also considering buyback through open market repurchase.

\section{REFERNCES}

1. Aaquith, Paul and David W. Mullins Jr.1986. Signalling with dividends, stock repurchases and equity issues. Financial management. 15(3) : 24-44.

2. Berk Jonathan and Peter DeMarzo.2008.Financial management. Dorling Kindersley (India) Pvt . Ltd. PP 18-33.

3. Brooks, Chris.2008. Introductory econometrics for finance. New York. Cambridge University Press. $2^{\text {nd }}$ Edition, pp 533-545.

4. Chakraborty, Madhumita.2009. The announcement of share buyback and market reaction : Evidence from India. International Conference on Business and Finance, held at Hyderabad during $9^{\text {th }}-10^{\text {th }}$ January.

5. Chan, Konan, David Ikenberry and Inmoo Lee. 2004. Economic sources of gain in stock repurchases. Journal of Financial and Quantitative Analysis. 39: 461-479

6. Damodaran, Aswath. 2008. Corporate Finance : Theory and Practice . New Delhi. Wiley India (P) Ltd. $2^{\text {nd }}$ Edition, pp 686-726.

7. D'Mello, Ranjan D and Pervin K. Shroff.2000. Equity undervaluation and decisions related to repurchase tender offers : An empirical Investigation. Journal of Finance. 55(5): 2399-2424.

8. Dittmar, Amy K. 2000. Why do firms repurchase stocks. The Journal of Business. 73 (3): 331-355.

9. Grullon, Gustavo and David L. Ikenberry.2000. What do we know about stock repurchases? Journal of Applied Corporate Finance. 13(1): 31-51.

10. Gujrati, Damodar N. and Sangeetha.2008. Basic Econometrics. New Delhi. Tata McGraw Hill Companies, Inc. $4^{\text {th }}$ edition: pp 593-647.

11. Horne, James C. Van, John M. Wachowicz Jr and Saumitra N. Bhaduri.2008.Fundamentals of Financial Management. New Delhi.Dorling Kindersley (India) Pvt . Ltd.12 ${ }^{\text {th }}$ Edition: pp 122-150.

12. Medury, Prasad V., Linda E. Bowyer and Venkat Srinivasan. 1992.Stock repurchases : A multivariate analysis of repurchasing firms. Quarterly Journal of Business and Economics. 31(1): 21-44.

13. Mishra, A K. 2005. An empirical analysis of share buybacks in India. ICFAI Journal of Applied Finance. 11(5) : 5-24

14. Subramanyam, Pratap G. 2008. Investment banking : Concepts, analyses and cases. New Delhi. Tata McGraw Hill Publishing Company Limited, pp 12.1-12.18.

15. Thirumalvalavan, P. and K. Sunitha.2005. Share price behaviour around buyback and dividend announcements in India. Indian Institute of Capital Markets 9th Capital Markets Conference Paper. 